\title{
Increasing The Ability of Environmental-Based Entrepreneurs Through Education
}

\author{
Priyo Subekti ${ }^{1}$, Hanny Hafiar ${ }^{2}$, Dian Wardiana Sjuchro ${ }^{3}$, Iriana Bakti ${ }^{4}$ \\ \{1priyo.subekti@unpad.ac.id, ${ }^{2} h a n n y h a f i a r @ g m a i l . c o m,{ }^{3}$ d.wardiana@unpad.ac.id \\ 4iriana.bakti@unpad.ac.id\} \\ 1,2,3,4 Universitas Padjadjaran
}

\begin{abstract}
Entrepreneurship education is an alternative education that can be chosen in secondary schools in an effort to reduce the unemployment rate because it can produce graduates who have the willingness and skills to open new jobs. Graduates have the ability to analyze and utilize the potential of the environment to become entrepreneurial potential. The research method uses the descriptive method by collecting data through direct observation and in-depth interviews with selected informants. The results of the study suggested that entrepreneurship of bamboo processing learned by the students includes: nursery of bamboo trees through polybags how to store bamboo trees; the introduction of bamboo processing into an economic value; introduction of the existing product and market distribution. Planting the spirit of entrepreneurship through education is influenced by several factors, namely: motivation of educators, learning media, parental support and the environment, interesting learning strategies and playmates.
\end{abstract}

Keywords: entrepreneurship; community empowerment; environmental potential; extracurricular education.

\section{Introduction}

Entrepreneurship is considered as a solution in an effort to accelerate the decline in unemployment and poverty. Besides being able to create jobs it also has broad usefulness because entrepreneurs are not only dealing with employees who are partners but also the wider community. Entrepreneurship can provide a significant contribution to reducing unemployment in the community and is an effective solution to suppress social problems. Good entrepreneurship emphasizes its efforts by involving the community by empowering the financially disadvantaged and skilled communities to move their businesses together to make a profit, and then the business results or profits are returned to the community to increase their income (Vial \& Hanoteau, 2015; Lisetchi \& Brancu, 2014; Iskandarini, 2014; Subekti, 2019). Talking about entrepreneurial skills for high school students is a very important ability to have because at present some unemployment in Indonesia actually comes from students or school graduates (Mulyani, 2011; Bak, 2018).

The following are data on potential labor, which is in the productive age in Indonesia (in millions): 


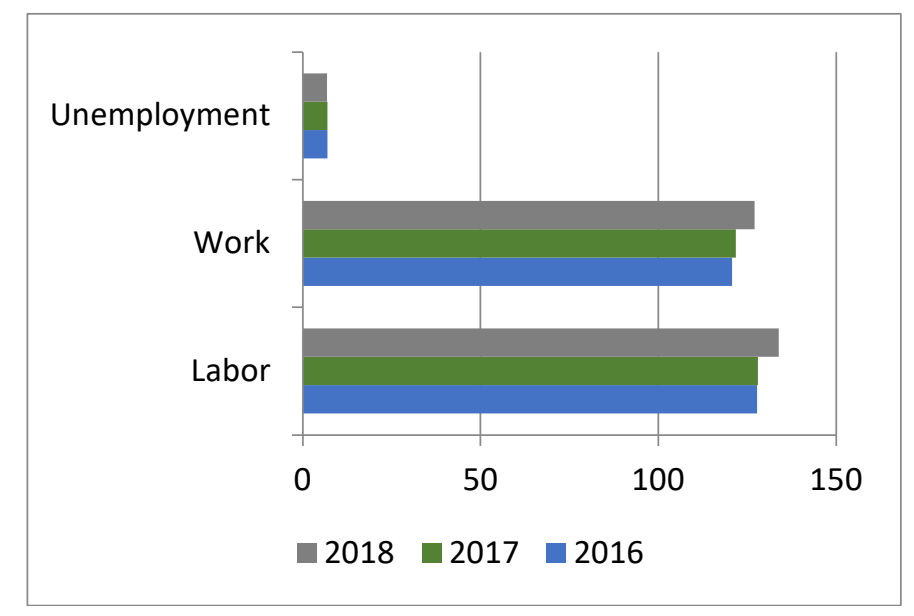

Fig.1. Labor and Unemployment Statistics (Absolute) in Indonesia Source: Central Statistics Agency 2018

To reduce unemployment, it requires graduates who can create jobs instead of just looking for work. This entrepreneurial ability can be grown through entrepreneurship education from an early age in lower secondary school. It is indicated that education in Indonesia does not pay enough attention to the growth of character and entrepreneurial behavior of students so that it seems only to prepare to become a labor [7]. Therefore, the development of entrepreneurial values in students can be one solution to solving the great problems of the Indonesian people in printing human resources with character and entrepreneurial spirit. Education in Indonesia should pay attention to the growing character and entrepreneurial behavior of students because in some other countries more attention to entrepreneurship education (Syifauzakia, 2016; Khulafa, Umami, Putri, \& Semarang, 2017).

\section{Methods}

Entrepreneurship education can be integrated into all subjects, local content, extracurricular activities, self-development, school culture or rules that are made by the school. Even entrepreneurship can be used as a competition event for students, for example; Art competition, cooking competition and product packaging so that it has selling points, handicraft competitions, and so on. Then the students' work is marketed and sold. Furthermore, each individual or group of contestants is given a score according to the assessment indicators that have been determined and awarded. So that it does not have to wait in advance for a mature design of the central government.

\section{Result and Discussion}

Entrepreneurship education in Muslimin Senior High School (SMA) Cililin, West Bandung Regency has become one of the extra-curricular activities or non-formal lessons that 
are outside of the hours of standard curriculum learning. The Muslimin High School is in Bongas Village which has a land area of $320 \mathrm{Ha}$, which has potential in the field of fisheries and bamboo trees.

Extra-curricular activities that have been held by schools are one of the potential media for character building including the character of entrepreneurship and improvement of the academic quality of students. Extra-curricular activities are educational activities outside the subjects to help the development of students according to their needs, potential, talents, and interests through activities that are specifically organized by educators and/or education personnel who are capable and empowered at school. The extra-curricular that is taught is about the processing of bamboo trees to be used as a craft that has economic value.

At first extra-curricular in the form of bamboo processing emerged from the results of observations made by the extracurricular teacher in Muslimin High School who saw the abundance of bamboo trees in Bongas Village and reflected on the success of the existing bamboo craftsmen. Financing for training capital for bamboo processing is currently still using self-help, descent between students and extra-curricular teachers.

One of the objectives of forming extra-curricular bamboo processing is: to instil a sense of love for the environment to students; Environment is a very important thing in life and damage to the environment has a huge impact on human life. Planting love for the environment needs to be instilled early, by introducing how to care for the environment that starts from a small environment, namely school. Garbage disposing in its place, separating between organic and non-organic waste, maintaining school cleanliness and the area around the school.

Environmental problems faced by humans are increasingly peaking this is due to human negligence. It is undeniable that along with the development of times, human ability to have an attitude of love for the environment is also decreasing. Today's society is more concerned with the development of technology and modern culture, rather than thinking about how to care for the environment. Although it seems trivial, having empathy for the surrounding environment is a capability that must be possessed by everyone. Traditionally, the natural environment is a resource under the responsibility of the government and society for its management, use, and protection. From this perspective, the goal of environmental management is to allocate natural efficiently and environmental resources to improve social welfare (Gurău \& Dana, 2018; Nasibulina, 2015).

Implant an entrepreneurial spirit early on; fostering student motivation to learn entrepreneurship and not relying on hopes to work in agencies or institutions as job seekers. Introduction of entrepreneurship from an early age will provide benefits for future provision later, with entrepreneurial learning from an early age will shape the personal students who are creative and able to capture the surrounding business opportunities [12]. The creativity that is trained early on, including through extra-curricular activities at school will become the main capital of productivity and student independence later on. Extra-curricular activities and selfdevelopment have considerable opportunities in entrepreneurial cultivation because schools can fully determine the type of extra-curricular activities and self-development for their students and have their own hours that are more effective than entrepreneurial insertion in the main subjects.

The implementation of activities for students is conducted through habituation and through core activities. Recognition through habituation is done through daily activities, such as washing hands and praying before and after eating, reflecting and dressing, combing hair, and arranging clothes, cleaning and arranging classes before going home, gardening, planting trees, and caring for animals. Introduction through core activities is carried out through fun, play, simulation, and creative activities according to developmental achievements and themes. 
To foster the values of entrepreneurial education, it is instilled from school age to habituate the value of entrepreneurship because it is by habituation that eventually an activity will become the property of students in the future (Sarkkaya \& Coşkun, 2015; Durrani \& Halai, 2018). Another reason why bamboo processing extras enter the extracurricular curriculum at Muslimin High School is that at present the community, especially the younger generation, still has the thought of finding work rather than creating jobs. In addition, there are still assumptions in the community that several types of jobs such as civil servants, bank employees, BUMN employees, and other private employees have brighter and more promising future prospects compared to entrepreneurship.

Utilizing the natural potential in Bongas Village, West Bandung Regency; introduce about bamboo trees in students, how to do the plant using poly bags, distinguish types of bamboo. Entrepreneurship bamboo processing education taught to students includes 1) nursery of bamboo trees through poly bags; 2) how to store bamboo trees; 3 ) the introduction of bamboo processing into an economic value; 4) introduction of the existing distribution of products and markets. To strengthen student learning motivation, collaboration with bamboo craftsmen has been successful. The collaboration is carried out in the form of sending students to bamboo producers to learn and practice directly on how to process bamboo into crafts and market it. Potential utilization of the environment so that economist is one of the strategies that are quite effective in entrepreneurship, environment-based entrepreneurship education has been widely applied by several countries, which suggests that environment-based education helps realize sustainable development that is future-oriented by taking into account ecological and social factors (Dressel, Ericsson, \& Sandström, 2018; Dhahri \& Omri, 2018).

The following are examples of student workshops that use bamboo so that it has economic value:
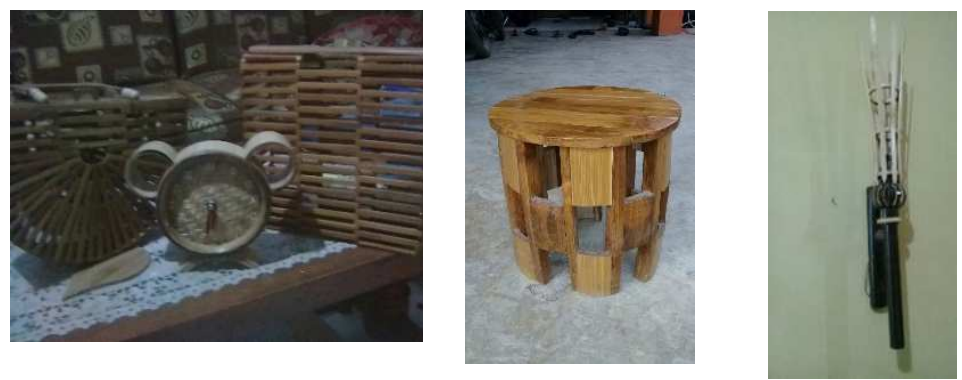

Fig.2.Workshops Result from The Students of Muslimin High School Cililin Source: research results

Factors that arise in the field findings and are able to influence the implementation of the cultivation of entrepreneurial values in students are:

Motivation by the teacher; educators have an important role in instilling the entrepreneurial spirit in students, by providing appropriate methods, techniques, models or strategies in entrepreneurship education (Henry \& Lewis, 2018; Braga, Proença, \& Ferreira, 2014; Chan, Uy, Chernyshenko, Ho, \& Sam, 2015). But to be able to achieve these goals educators must have basic skills regarding entrepreneurship and have been or are directly involved in an entrepreneur so that they can become examples of models for students. This is confirmed by several studies which suggest that training is given to teachers at the level of basic education 
related to entrepreneurship education (Zahra, Gedajlovic, Neubaum, \& Shulman, 2009; Javalgi \& Grossman, 2016).

Instructional Media; Learning media used in entrepreneurial education activities include bamboo materials and direct practice. Besides that, support from parents; one of the external factors that influence student motivation in entrepreneurship is the role of parents and family, this happens because all this time there is a growing thinking among parents of students who think that entrepreneurship is difficult, requires a long time to resolve and has the possibility of failure big. Family and parent support is an important social capital in the cultivation of the entrepreneurial spirit, this is confirmed by research that suggests the importance of the role of the family in the process of cultivating the entrepreneurial spirit (Anderson \& Miller, 2003; Ismail, Husin, Abdul, Mohd, \& Che, 2016).

An interesting learning process and direct practice or learning by doing and the influence of peers influence student motivation in the cultivation of entrepreneurial values. The practice is directly done through collaboration with bamboo entrepreneurs so that students can see and learn directly.

\section{Conclusion}

Entrepreneurship education in secondary schools is an important education because it can equip students in terms of willingness and entrepreneurial skills. Thus secondary school graduates have the choice of whether to go to school or open up entrepreneurship which of course can create jobs.

Entrepreneurship education in Muslim high schools utilizes the existing environmental potential, namely the potential of bamboo trees being created to have economic value. One important factor in entrepreneurship education is external factors which include: parental support, the motivation of educators, support from the environment and friends.

\section{References}

[1] V. Vial and J. Hanoteau, "Returns to Micro-Entrepreneurship in an Emerging Economy: A Quantile Study of Entrepreneurial Indonesian Households' Welfare," World Dev., vol. 74, pp. 142-157, 2015, doi: 10.1016/j.worlddev.2015.04.008.

[2] M. Lisetchi and L. Brancu, "The Entrepreneurship Concept as a Subject of Social Innovation," Procedia - Soc. Behav. Sci., vol. 124, pp. 87-92, 2014, doi: 10.1016/j.sbspro.2014.02.463.

[3] Iskandarini, "The Impact of Entrepreneurial Barrier toward Entrepreneurial Intention for Decreasing Unemployment through Community Empowerment," Procedia - Soc. Behav. Sci., vol. 115, no. Iicies 2013, pp. 166-174, 2014, doi: 10.1016/j.sbspro.2014.02.425.

[4] P. Subekti, "ENVIRONMENTAL ENTREPRENEURSHIP EDUCATION : CASE STUDY OF COMMUNITY EMPOWERMENT PROGRAMS IN BANDUNG BARAT DISTRICT , INDONESIA," Int. J. Entrep., vol. 23, no. 2, pp. 1-13, 2019.

[5] E. Mulyani, "Model Pendidikan Kewirausahaan di Pendidikan Dasar dan Menengah," J. Ekon. dan Pendidik., vol. Vol. 8, no. 1, pp. 1-18, 2011.

[6] H. Bak, "Beyond the economy: Education for development," Kasetsart J. Soc. Sci., 2018, doi: 10.1016/j.kjss.2018.06.001.

[7] S. Aparicio, D. Urbano, and D. Audretsch, "Institutional factors, opportunity entrepreneurship 
and economic growth: Panel data evidence," Technol. Forecast. Soc. Change, vol. 102, pp. 4561, 2016, doi: 10.1016/j.techfore.2015.04.006.

[8] Syifauzakia, "Penanaman Nilai-Nilai Kewirausahaan Pada Anak Usia Dini Melalui Metode Proyek," Tunas Siliwangi, vol. 2, no. 1, pp. 92-113, 2016.

[9] F. N. Khulafa, F. Z. Umami, R. H. Putri, and U. N. Semarang, "Pengembangan pendidikan kewirausahaan di sekolah dasar," in Seminar Nasional Pendidikan PGSD UMS \& HDPGSDI Wilayah Jawa, 2017, pp. 146-153.

[10] C. Gurău and L. P. Dana, "Environmentally-driven community entrepreneurship: Mapping the link between natural environment, local community and entrepreneurship," Technol. Forecast. Soc. Change, vol. 129, no. November, pp. 221-231, 2018, doi: 10.1016/j.techfore.2017.11.023.

[11] A. Nasibulina, "Education for Sustainable Development and Environmental Ethics," Procedia Soc. Behav. Sci., vol. 214, no. June, pp. 1077-1082, 2015, doi: 10.1016/j.sbspro.2015.11.708.

[12] M. Ahunov and N. Yusupov, "Risk attitudes and entrepreneurial motivations: Evidence from transition economies,” Econ. Lett., vol. 160, pp. 7-11, 2017, doi: 10.1016/j.econlet.2017.08.016.

[13] M. Sarıkaya and E. Coşkun, "A New Approach in Preschool Education: Social Entrepreneurship Education,” Procedia - Soc. Behav. Sci., vol. 195, pp. 888-894, 2015, doi: 10.1016/j.sbspro.2015.06.368.

[14] N. Durrani and A. Halai, "Dynamics of gender justice, conflict and social cohesion: Analysing educational reforms in Pakistan,” Int. J. Educ. Dev., vol. 61, no. June 2017, pp. 27-39, 2018, doi: 10.1016/j.ijedudev.2017.11.010.

[15] S. Dressel, G. Ericsson, and C. Sandström, "Mapping social-ecological systems to understand the challenges underlying wildlife management," Environ. Sci. Policy, vol. 84, no. September 2017, pp. 105-112, 2018, doi: 10.1016/j.envsci.2018.03.007.

[16] S. Dhahri and A. Omri, "M P RA Entrepreneurship Contribution to the Three Pillars of Sustainable Development: What Does the Evidence Really Say? Entrepreneurship Contribution to the Three Pillars of Sustainable Development: What Does the Evidence Really Say? Anis Omri," World Dev., vol. 106, pp. 64-77, 2018, doi: 10.1016/j.worlddev.2018.01.008.

[17] C. Henry and K. Lewis, "A review of entrepreneurship education research," Malaysian J. Learn. Instr., vol. 60, no. 3, pp. 263-286, 2018, doi: 10.1108/ET-12-2017-0189.

[18] J. C. Braga, T. Proença, and M. R. Ferreira, "Motivations for social entrepreneurship Evidences from Portugal," Tékhne, vol. 12, no. 2014, pp. 11-21, 2014, doi: 10.1016/j.tekhne.2015.01.002.

[19] K. Y. Chan, M. A. Uy, O. S. Chernyshenko, M. H. R. Ho, and Y. L. Sam, "Personality and entrepreneurial, professional and leadership motivations," Pers. Individ. Dif., vol. 77, pp. 161166, 2015, doi: 10.1016/j.paid.2014.12.063.

[20] S. A. Zahra, E. Gedajlovic, D. O. Neubaum, and J. M. Shulman, "A typology of social entrepreneurs: Motives, search processes and ethical challenges," J. Bus. Ventur., vol. 24, no. 5, pp. 519-532, 2009, doi: 10.1016/j.jbusvent.2008.04.007.

[21] R. R. G. Javalgi and D. A. Grossman, "Aspirations and entrepreneurial motivations of middleclass consumers in emerging markets: The case of India," Int. Bus. Rev., vol. 25, no. 3, pp. 657667, 2016, doi: 10.1016/j.ibusrev.2015.10.008.

[22] A. R. Anderson and C. J. Miller, "Class matters': Human and social capital in the entrepreneurial process," J. Socio. Econ., vol. 32, no. 1, pp. 17-36, 2003, doi: 10.1016/S10535357(03)00009-X.

[23] I. Ismail, N. Husin, N. Abdul, M. H. Mohd, and R. Che, "Entrepreneurial Success among Single Mothers: The Role of Motivation and Passion," vol. 37, no. 16, pp. 121-128, 2016, doi: 10.1016/S2212-5671(16)30102-2. 